\title{
High school students as researchers about their school: exploring its potential for choices and skills
}

Improving Schools

(C) The Author(s) 2021

Article reuse guidelines: sagepub.com/journals-permissions DOI: I0.I I77/I36548022। I001967 journals.sagepub.com/home/imp

@SAGE

\author{
Ana Cristina Torres \\ University of Porto, Portugal
}

\section{Ana Mouraz}

University of Porto, Portugal

Universidade Aberta, Portugal

\begin{abstract}
This paper introduces a partnership between researchers in Education Sciences and high school students and discusses the students' perceptions of the effects of taking on the role of researchers in Education Sciences. These partnerships were established to develop a project in which high school students researched their school's everyday life in collaboration with academic researchers. The partners are introduced, as well as the partnership and the steps for supporting the student researchers in developing their projects. Drawing on student voice literature, a qualitative evaluation of the students' products and perspectives regarding their experiences as researchers pointed to the potential of these partnerships for the students' engagement in discussions about educational trajectories and pathway choices with their peers, teachers and researchers. Moreover, the students' perceptions indicate an improvement in their inquiry skills and valuing of research in Education Sciences. This paper adds to the existing literature on student voice in schools, by discussing processes to engage students as researchers of school issues and by highlighting the importance of student voice to early awareness and recognition of research in Education Sciences.
\end{abstract}

\section{Keywords}

Partnerships in education, research partnerships, students as researchers, student voice, upper secondary

\section{Introduction}

This paper introduces a partnership between researchers in Education Sciences and high school students aged 16 to 18 who developed research projects about their schools. It also discusses the students' perspectives regarding the effects of taking on the role of researchers in Education Sciences, on their improvement of inquiry skills and development and awareness of research in Education Sciences.

\section{Corresponding author:}

Ana Cristina Torres, Centre for Research and Intervention in Education, Faculty of Psychology and Education Sciences, University of Porto, Rua Alfredo Allen, 4200-I35 Porto, Portugal.

Emails: acctorres@fpce.up.pt; https://www.cienciavitae.pt/portal/85I6-A4BF-A2E I 
These research projects occurred within a partnership between a Faculty of Education Sciences and a high school of a Portuguese city, arranged within a municipality's project entitled 'Society, School and Research'. This project challenged several of the city's public higher education institutions to partner with public middle and high schools in school-based projects aiming to promote the scientific literacy of students. The starting point of the partnership reported here was to encourage high school students to research about their school's everyday life, including the challenges in their schooling and life trajectories. University researchers, including the authors, assumed a supervisor role by helping the high school students to define and shape research issues selected according to their interests and experiences.

Although a consistent body of research and practice has included students' voices, students remain more often passive respondents rather than active researchers or research partners (Fielding, 2011; Gonzalez et al., 2017; Lundy \& Cook-Sather, 2016; Mockler \& Groundwater-Smith, 2015). Students are more often the analysed subjects in educational research, with little say in what is researched and how it is translated by whoever is performing the analysis (Cook-Sather, 2012). This scenario is slowly changing, with students increasingly being invited to partner with teachers and university researchers to explore topics such as marginalization (Messiou, 2014), engagement/ disengagement (Carrington et al., 2010), curriculum development and teaching practices (Davies, 2011; Leat \& Reid, 2012; Morgan \& Porter, 2011; Smit, 2013). But while the focus has mostly been put on issues of school improvement and social inclusion, the potential of these partnerships for the students' awareness of Social Sciences research and Education Sciences specifically has remained unexplored.

In Portugal, though school-university partnerships have long been frequent, students participating as researchers in educational issues is mostly limited to sporadic initiatives in Higher Education. When considering the wider field of student voice, some work in primary or secondary schools has been developed to capture students' schooling experiences (Pereira et al., 2014) or for its potential for inclusive student participation (César \& Oliveira, 2005; Messiou et al., 2016) and curriculum or school improvement (Messiou et al., 2016; Ministério da Educação, 2016; Torres \& Mouraz, 2015). Small steps have been taken towards more participatory types of research, namely under the aim of citizenship education (Menezes \& Ferreira, 2014). Nevertheless, concerning student participation in school life, conceptions of what democracy involves have been limited and participation is often confined to some representation on official committees (Pereira et al., 2014).

There has been a considerable international boost to involving students as researchers in schools through the discursive framings of higher standards and school improvement (Thomson \& Gunter, 2006), and from the children's rights legally established by the UN Convention (Lundy \& CookSather, 2016; United Nations, 1989). However, the stimulus of the project here reported was located more on inquiry-based learning for scientific literacy, research awareness and the increase of post-school aspirations. In this specific partnership, the involvement of high school students with research facilitators from the field of Education Sciences who, in turn, acknowledged the state of low student participation in the decision making within schools, inevitably led to a focus on schooling and curriculum issues more than on traditional disciplinary issues (most frequently STEM). Our standpoint was, primarily, the development of students' inquiry skills and views of research in Education Sciences rather than the issues of children's rights. Nevertheless, we took the opportunity to encourage students to come up with issues that were a part of their day-to-day concerns, to raise the school's awareness about unsolved or unattended problems as much as about the importance of student participation in school life. Thus, our paper adds to the existing literature on student voice in school and curriculum development, with the students' perspectives about their experiences as knowledge producers in Education Sciences and enablers of discussions around school improvement. 


\section{Students as researchers and student voice}

The term student voice has been increasingly used within a very wide range of initiatives, operationalized in diverse ways and under a variety of terminologies (Cook-Sather, 2018; Gonzalez et al., 2017; Lundy \& Cook-Sather, 2016). Whether the focus emerges from the democratic exercise in education (Fielding, 2011; Menezes \& Ferreira, 2014; Pereira et al., 2014), the children's and young people's rights movement (Lundy \& Cook-Sather, 2016), school improvement (Davies, 2011; Roberts \& Nash, 2009), participatory or action research (Bland \& Atweh, 2007; Smit, 2013) or inquiry-based learning (Leat \& Reid, 2012; Quintero, 2010), the view is one that aims towards empowering learners in issues of their own education and lives. Listening to the voices of children and young people concerning school and the curriculum has been defended under premises of the social-educational, ethical-political, innovation and epistemological spheres (Bourke \& Loveridge, 2018; Gonzalez et al., 2017; Pereira et al., 2014; Smit, 2013). However, student voice is still very much anchored to consultancy movements, which raises questions of misrepresentation and continues to place authority and agency with researchers or other adult educational actors (CookSather, 2012). In looking to overcome some of these issues, recent research has been addressing issues of power imbalances, politics of student voice and actual impacts on school leadership (Gonzalez et al., 2017). Consequently, its framing has been shifting from research on to research with students in partnerships (Bourke \& Loveridge, 2018; Cook-Sather, 2018; Fielding, 2004b, 2011; Fine et al., 2007; Mitra, 2009; Mockler \& Groundwater-Smith, 2015).

For Thomson and Gunter (2006), the activity of students as researchers has been framed under two main distinctive discourses. Within a school improvement discourse, teachers place students in the role of researchers by involving them in the analysis at the school level and interpretations of practices and experiences within national educational policies, as a more effective path to change. Whereas under a rights framework, the discourse tends to shift to the students' right to have a say in the nature, scope and form of research they conduct, as well as to be actively engaged in making recommendations and implementing change (Fielding, 2001, 2004b). This connects with the definition of students as researchers, proposed by Fielding (2004a, 2004b), as a partnership that privileges an egalitarian dialogue between both parties, students and adult research facilitators. Distinguishing it from other youth participatory methods of research (Fine et al., 2007), Fielding (2004a, 2004b) goes on to explain how, in the process of students as researchers, students have the leading role in identifying issues to be researched, in conducting the research, analysing the data, writing the report and presenting their findings. This gives students the responsibility to communicate the various processes and findings of the research with respect, attentiveness and commitment to enact positive change.

The challenges of this responsibility and increased agency in the production and dissemination of knowledge (Bland \& Atweh, 2007) were explicitly addressed in Fielding's typology of patterns of partnership between students and adults in schools (Fielding, 2011): students as knowledge creators, students as joint authors and intergenerational learning as participatory democracy. The path from the first to the last implies increased participation and authorship of students in decisionmaking and implementing the course of action, thus progressing to a more equal sharing of power and responsibility.

\section{Students as researchers: Raising awareness of Education Sciences research and learning about inquiry skills}

The rights framework reminds us it is not just a matter of increasing children and youth participation, but rather a responsibility to afford students respect and promote their skills to become 
confident and active partners in research (Cook-Sather, 2018). Therefore, most students as researchers projects involve a training component, either through specific documents or training sessions. For instance, Fielding and Bragg (2003) put forward an outline of questions to guide the steps for students as researchers' projects, which included:

- Involving students (which students to include? are they invited or do they volunteer?);

- Choosing topics to research (who decides? where is the real chance of change?);

- Establishing staff roles (how much will they lead and how much will they follow students' lead?);

- Matching inquiry strategies to the topic (what are appropriate ways to find answers to the research questions posed?);

- Setting a time scale and distributing tasks among those involved;

- Analysing and writing up data (keeping records, identifying patterns, drawing conclusions, etc.);

- Sharing the findings (format? audience? purpose?);

- Celebrating it;

- Responding to it.

Thomson and Gunter (2006) developed a research toolkit to help students generate research questions and to analyse and decide on appropriate methods to answer the posed questions. Also, issues such as the different types of data produced and their implications or ethical issues surrounding confidentiality and access were discussed with the students.

Kellett (2005) and Morgan and Porter (2011) proposed training sessions covering topics such as the nature of research - often addressing the positivist versus interpretivist approaches: reading and reviewing existing research, research questions, appropriateness of specific methods to the research topics, uses of quantitative and qualitative data, data analysis and dissemination of findings. Research ethics was also addressed, with issues such as validity, representativeness, reliability. Carrington et al. (2010) went further by proposing a three-stage model for training middle school students as researchers. The first stage was a 2-day workshop for students and staff, in which expectations of role and responsibilities were established, a shared understanding of the overarching research focus was promoted, research methods were presented and school-based projects were planned. Stage 2 involved undertaking school-based projects throughout a whole year with the support of university researchers. Stage 3 included a 1-day conference for students to share their work with other students, school staff, families and community members.

Though no specific initiative was found focusing the potential of students as researchers' projects in the awareness of research in Education Sciences, its potential has been signalled as a way of enabling inquiry-based learning opportunities (Leat \& Reid, 2012). Moreover, and according to Kellett (2005), the active engagement of students in research processes is a good stimulus for the development of metacognition and critical thinking, as well as data and information organization and management skills. Furthermore, learning to focus on research questions and choosing appropriate objectives and methodologies to answer those questions promotes logical and lateral thinking and the transfer of learning to other contexts. Data analysis seems to be the most valuable stage to promote such high-order thinking skills, and disseminating findings allows students to develop their writings, communication and organizational skills. Besides the development of such inquiry skills, Morgan and Porter (2011) have also highlighted how students as researchers' programmes offer students opportunities to work with adults (university researchers and senior staff) and to collaborate with peers (developing skills of negotiation, communication and teamwork organization), while also improving their attitudes towards school. 


\section{The research partnership and partners}

Since 2015, the promoters of the project 'Society, School and Research' have been challenging public high schools in the city to partner with specific public higher education institutions in order to develop inquiry-based projects in which students assume the role of researchers. These partnerships have the overall objective of promoting students' access to scientific research and knowledge production, as well as raising their levels of scientific literacy, aiming, more specifically, towards promoting increased dissemination of the research developed in the city's R\&D institutions; actions to stimulate further and higher education while also attracting young people to a research career; proximity relationships between different institutions of the city; and school success. Each research partnership has resulted in school-based projects developed throughout one school year.

The specific research partnership here described involved a Faculty of Education Sciences and a public high school. Within the Faculty, two senior researchers and three junior researchers were involved. These researchers work in the fields of curriculum studies and teacher training, which are quite strong within the Faculty's teaching, research and intervention activity.

The school is a high school located on one of the city's former lyceums (grammar schools) of the early 20th century, but has since gained renovated premises in the city's centre. It is a part of a cluster of four schools with a total of approximately 1,600 students - from which approximately 600 attend upper secondary education: 180 teachers and 60 members of non-teaching staff. Almost half of its students are supported by special social benefits. In Portugal, most public schools are organized in school clusters. Most of them provide from pre-school to the end of lower secondary education in what is called Basic Education. So, many students have to change school when they move on to upper secondary education even though this schooling level has been compulsory since 2009. Other school clusters, such as this one, include also upper secondary education. Its central location in the city with several public transport services nearby, makes it also attractive to students who have to move to a different school when finishing their Basic education in school clusters which lack upper secondary. In Portugal, upper secondary education courses are 3-year fixed study programmes with an educational tracking between academic, artistic and vocational education courses to be attended from the 10th grade to the 12th grade. There are four options of academic courses - Sciences and Technologies; Languages and Humanities; Socioeconomic Sciences; Visual Arts - which are usually the most popular, and several specific artistic and vocational educational options with different distributions between schools. Another consequence of the enlargement of compulsory schooling up to the 12th grade (age of 18) was that most public schools began expanding the diversity of their educational offers between more academic and more vocational courses. This particular school has a highly academic culture but also offers some vocational education courses, making its student population diverse in terms of attainment and academic paths. Nevertheless, more than $70 \%$ of its students are in academic courses with a successful attainment in their schooling paths within the national averages. ${ }^{1}$

A first meeting between the team of university researchers (UR) and the school's management team allowed for all to agree upon engaging upper secondary education students, aged 16 to 18 , from academic courses, on a voluntary basis. It was somewhat a compromise between the school's intentions of reaching a specific group and giving a choice to students to participate, thus engaging more committed students. In this school, there was some consensus that students who already had aspirations to higher education might benefit from participating and gain an understanding of university culture and practices, thus paving the way for a more successful transition to higher education. It was also decided that each group of student researchers (SR) should be tutored by one school teacher, also on a voluntary basis. These tutor teachers were asked to assist students with organizing time and tasks, encouraging and discussing processes and findings, anticipating difficulties, acting 
as go-betweens with other school staff and students and giving emotional support and incentive to students. As pointed out by Fielding and Bragg (2003), active teacher engagement also provided increased credibility to the work of student researchers, within the school community. Finally, the following partnership objectives were set:

- To develop the students' research competencies, attracting them to careers in research.

- To increase the students' recognition and appreciation of research in the field of Social Sciences in general, and Education Sciences specifically.

- To produce empirical knowledge that could be useful to the student researchers involved, as well as to their school improvement.

After the first meeting, the educational project coordinator in the school engaged a few interested school teachers, who disseminated the proposal in the classes. However, the students' projects were developed as an extracurricular project, like other activities such as clubs, sports and incentives to participate in contests and international exchange actions.

In 3 years, this partnership engaged 20 girls and 4 boys in the 12th grade, 9 girls and 4 boys in the 11th grade, 4 girls and 1 boy in the 10th grade and 4 girls and 1 boy in the 11 th grade who repeated the project while in the 12th grade. These student researchers were organized into nine research teams: three of them composed of 12th grade students attending a Languages and Humanities course, and the others composed of students enrolled in a Sciences and Technologies course, though in different grades. Both courses are academic courses and shaped as a preparation stage for higher education studies. Consequently, these students were highly concerned with attainment and high-stakes exams which, in Portugal, have a strong weight in credits to access higher education courses.

Since most of the work on the projects had no explicit recognition in terms of curriculum or teaching schedules, teacher engagement varied widely according to the SR teams. Different SR teams were supervised in the school by specific teachers from different subjects (Psychology, Sociology, Portuguese Language) and by the school's educational project coordinator, who had no teaching function in the school. The UR constantly pushed for tutor teachers to assume a coresearcher role in each research group, not only as important support for the whole research project, but foremost for the action to follow it (Roberts \& Nash, 2009). The most active adult school participant was the educational project coordinator who played a pivotal role in negotiating the research problems with both the UR and the SR, and in facilitating the SR access to other students and teachers to participate in data collection.

\section{The development of the students' research projects}

After this initial recruitment, the UR organized an introductory seminar in the school with those students who expressed an interest in participating, in order to present the aims, timeline, expected workload, expected outcomes and products of the project. This seminar was also useful to help the students organize research teams of four to five students. Usually, the teams were organized depending on the students' relationships and research interests. Their participation was presented as an educational opportunity more than as a research process. The school organized informed consent forms that were passed on to both the students and their parents/guardians. Keeping in mind the promoters' aim of fostering the student access to scientific research and knowledge production, as well as their levels of scientific literacy, the team of UR designed a project scheme that tried to fulfil this aim within the field of Education Sciences, which is illustrated in Figure 1. 


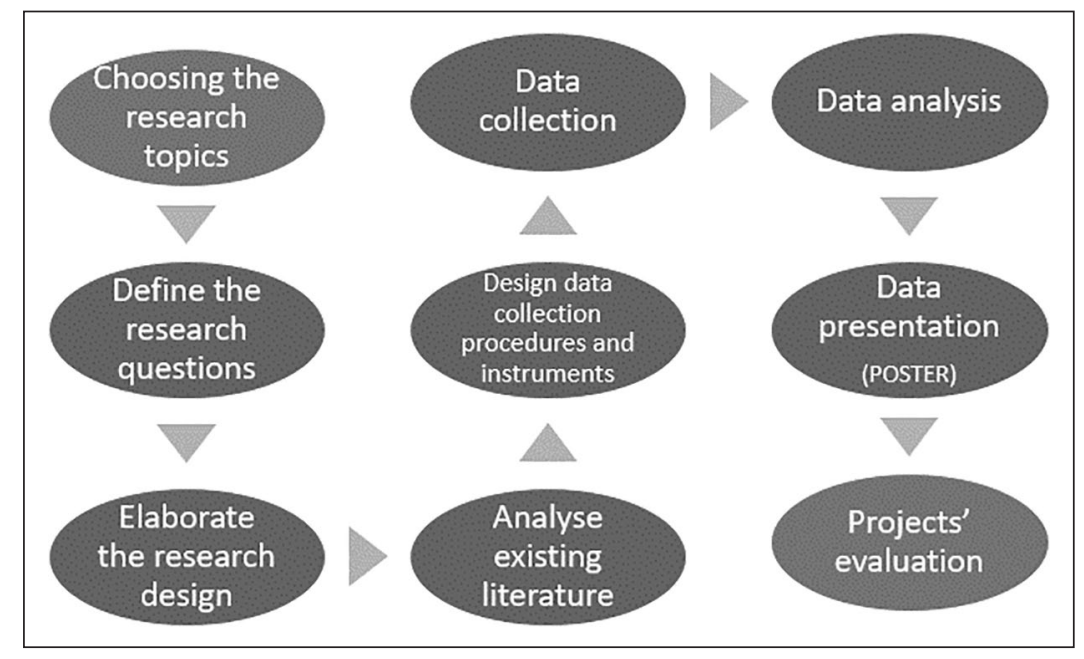

Figure I. Research partnership project scheme.

Thus, this scheme was designed to engage the students in research procedures which might develop their competencies in problematizing social and educational issues related to their lives and education trajectories. Like Roberts and Nash (2009), we wanted to encourage students to reveal multiple and unusual perspectives about teaching and learning, as well as about their everyday school lives. Thus, this allowed the students to have some power in choosing the research issues.

To offer some stimulus, we proposed two broad themes that also emerged from a consensus between the UR and the school management team: everyday experiences within the school and challenges in the students' schooling trajectories. Students had the power to choose research topics within these themes, because, as in the project by Bland and Atweh (2007), we acknowledge that students have the closest knowledge of their school's problems, so they should be regarded as the principal researchers in the collaboration. However, some negotiation of these topics occurred with the UR, the tutor teacher and the school's educational project coordinator. The students' engagement in this selection process and its negotiation also had the potential to provide a more realistic view of the complexities of scientific research and thinking, as well as of the importance of argumentation skills for it (Kuhn et al., 2008).

Subsequently, the UR helped the SR to define a research problem, in a more individual session with each team, which was organized in such a way as to value the students' ideas and discuss with them the relevance and feasibility of specific topics that they expressed willingness to address. Thus, the UR helped the SR to focus on more specific research issues and define research questions, as well as to think about possible research designs, which included careful analysis of the pros and cons of which participants to question, what questions to ask and how to ask them. The selected research questions were mostly related to schooling challenges, with a special focus on the one related with the possibility of moving to Higher Education, and individual and social wellbeing, such as student stress, excessive use of mobile phone, quality of the school canteen food. Student perceptions about extra-class lectures and high school courses and subjects were amongst the only curriculum issues selected.

A second meeting, 2 weeks after, was aimed at analysing some literature about the research topics and settling the target audience to inquire, as well as the data collection methodologies to use. 
Due to restrictions of timeline and students' training, data collection methodologies were limited to individual interviews, surveys and observation, as other more complex procedures required more intensive training and skills that were not possible to provide within the project timeline and resources. The UR and the SR then defined some questions to pose to the target audience.

A third meeting was used to design data collection procedures and instruments, including highlights of ethical principles, such as anonymity and confidentiality, and procedures such as consent terms and how to avoid the collection of sensitive data (if not needed).

Afterwards, with the help of the supporting teacher, the SR proceeded with the data collection, always within their school's premises and community, to meet the outlined project's objectives. In one case, the project comprised data collection with former students from the school who had moved on to higher education. After these procedures, the UR organized a scientific writing seminar to explain to the SR and their tutor teachers how to produce an abstract and a research poster. While most of the small group sessions took place in the Faculty's premises to facilitate the SR access and acquaintance with the university premises and environment, the seminars always took place in the school's premises. Data analysis, when quantitative, was done collaboratively with the UR when there was a need for specific statistical analysis. However, for qualitative data analysis, the UR usually initiated the students in simple content analysis, which they were able to perform afterwards.

A fourth and a fifth meeting were organized, for the SR, tutor teacher and the UR together, to analyse and discuss findings and design a research poster. The poster and project presentation usually occurred between mid-April and the beginning of May, in a public conference where all the partnership projects were presented. Lastly, the authors organized a project evaluation with the partner SR.

\section{Research methods: Evaluating student researchers' experiences}

Our paper discusses processes to engage students as researchers of school issues. Thus, the paper presents and discusses the effects reported by student researchers from researching in Education Sciences, for both their inquiry skills competences as well as their recognition and appreciation of research in Education Sciences.

Data were collected from the evaluations of the project, organized at the end of each school session and from the abstracts of the posters the students produced and presented in the project's final conference.

The evaluation of the project had a qualitative nature and was organized to allow the students in each research team to evaluate their participation in the project, as well as the project itself. It involved a group interview with each research team (10 group interviews), in which the SRs' perspectives were collected through questions about (a) the overall organization and scientific development of the project; (b) perceived effects of their participation in the research partnership on their learning and academic and professional expectations; (c) their experience of collaborating with UR, with the university and with research in Education Sciences. The collective interviews were recorded and transcribed, and their transcriptions, together with notes from the interviews and abstracts from the produced posters, were subjected to a content analysis using NVivo. Content analysis focused mainly on the students' perspectives about the benefits of assuming the role of researchers.

\section{Results: Students' perspectives about the benefits of being researchers about their schools}

The SR's answers reflected two main types of perceived benefits: their deepening of the researched issues and problems, as well as benefits from researching in partnership with university researchers and with the specific procedures described in previous sections. 
Regarding the researched issues, most of the students appreciated the experience for helping them to reflect and decide upon academic and career paths (15 references/students). They also mentioned it was important for them as they became more aware of educational and social issues in their daily contexts (11 references/students). One student reported having 'realized that there are several students like me who still don't know what they want to do in the future, and that there are several ways for me to look for help to decide and even for the school to help me with that decision'. Still, all the students $(n=27)$ who participated in the interviews mentioned attending higher education as an expectation for their academic future, though only four of them admitted that participating in this project helped them to better shape their course options.

Another mentioned benefit associated with researching in partnership with university researchers was the possibility of early contact with the university staff and environment (eight references/students), since, in addition to informal $\mathrm{s}$ with the university researchers, there were meetings at the Faculty and several exchanges of work e-mails and messages. Consequently, students highlighted as positive the fact they were able 'to interact with the university environment and to develop some abilities to develop a research project/study'. As such, the possibility of developing research competences and teamwork, by communicating, being analytical, creative, methodical and independent in tasks, was also mentioned by several students (nine references/students). From these, teamwork and interpersonal relationships were amongst the project's aspects that were most appreciated by students (15 references/students). The students also highly appreciated the fact they had an active role in the selection of the research topics (14 references/students) and they could apply data collection methods from social sciences amongst their colleagues (10 references/students). Being allowed to discuss their concerns and analyse their findings with the university researchers was also highlighted (12 references/students).

Finally, increased awareness for research in Education sciences also emerged from the SRs' answers (eight references/students), as most of these students were in Sciences and Technology studies. One of these students explained that 'we understood that Science (as Research) can be made of many several things and not just Technology and Health, as we are used to hearing about'. Some students also referred to having realized that carefully planning all the research from the beginning is of the utmost importance (four references/students). In this respect, one student stated, for instance, that she 'thought that everything was more spontaneous', and another student explained that 'many times I read a study, saw the result, and never thought about the amount of work behind it. Our project was a small research. When it is research about a very important theme, it must be a huge amount of work'. Some of the comments from students also had to do with taking into consideration the contexts in analysing, discussing and reporting the data, as they realized that the gathering of data may not always lead to a generalization of conclusions.

Finally, some difficulties mentioned by the students must also be acknowledged, as they may have posed barriers to the amplification of the benefits of these partnerships. The fact that all the research work was extracurricular posed some planning and scheduling problems, sometimes preventing more meetings among the UR and SR, particularly with the tutor teachers. As such, the students also referred to an insufficient connection of the research with curriculum and classroom tasks, as a barrier to better development of their projects (11 references/students).

\section{Discussion}

The benefits from this experience reported by students highlight the potential of participating in a research process such as this to the improvement of students' self-confidence regarding their future choices and pathways, not only by becoming more informed about different opportunities but also 
because, as reported in previous literature (Bland \& Atweh, 2007; Messiou, 2014), when these projects involve visits to university campuses or discussions of post-school options, students can become more familiar and comfortable with higher education environments and actors, as well as raise their expectations of post-school education. They also become better equipped with analytical and social skills to deal with the challenges and difficulties usually posed by transitioning to higher education, particularly problematic in Portugal (Mouraz, \& Sousa, 2016). Even the practical experience of leaving their familiar school premises and taking public transportation to go to the Faculty's premises to discuss their ideas and doubts with the university researchers, in a balanced way, stimulates autonomy in solving practical problems and ease in communicating with adult university actors. Thus, we concur with Fielding and Bragg (2003) and Roberts and Nash (2009) in the idea that student researchers develop a positive sense of self, agency, inquiry skills and social competences. These, in turn, can lead to improved creativity, reflexivity, communication skills and teamwork skills both in and outside classrooms (Bland \& Atweh, 2007; Leat \& Reid, 2012; Messiou, 2014).

Another important aspect is the improvement of students' awareness of the problems and challenges in their school, already reported by Fielding and Bragg (2003), particularly through an improved understanding of other young people's positions towards the issues they raised. While some of these issues carried some of the students' personal assumptions, often quite individualized in their own experiences or shaped by commercialized youth cultures, as well as schooling and social types of sorting and ranking (Thomson \& Gunter, 2006), the collaborative processes in which the students engaged seemed to challenge their assumptions and pave the way for the development of more analytical thinking skills and a more open mind towards other views, experiences and solutions.

Finally, we believe that the potential of student researcher processes for a better understanding of the importance and epistemology of Social Sciences in general, and Education Sciences in particular, has emerged in some of the participating students' reports. Along with other project-based and inquiry-based teaching methods, student researcher projects have the potential to contradict very widely installed positivist and closed views of research in the ways curricula are designed (Goodson, 2005), still highly associated with more experimental sciences, in which the discovery and the method have a superior status concerning problematizing, discussing, communicating and negotiating hypotheses and findings. The novelty of approaches like these is to highlight the importance of engaging educational actors other than more traditional recognized experts as valuable agents of research, which in turn can increase the status of Educational Sciences as a research discipline.

This was a learning and development opportunity for the university researchers as well. While supporting student researchers, adult university researchers have developed their epistemic agency and a capacity to construct more legitimate knowledge, preventing the often established distance between 'the knowing agent and the object of knowledge' (Fielding, 2004b, p. 305). Also being concerned with issues of transition to higher education, as in Bland and Atweh's (2007) project, we had the opportunity to gain unique knowledge of barriers to students' tertiary aspirations, as well as expectations they have towards post-school options.

\section{Conclusion}

The benefits of participatory research initiatives as those involving university researchers collaborating with high school student researchers in projects that raise and secure firmer options of future pathway choices has been well established. We here highlight the potential of these projects not only through the students' contact with higher education environments but also through socializing 
possible options with both the university researchers, their teachers and peers through more structured research approaches.

Despite the recognized potential of this project, we must acknowledge one limitation in this work that relates to our student voice framework. As much as we defend the potential of these projects to promote students' voices and participation, we concur with previous alerts (Bourke, \& Loveridge, 2018; Roberts \& Nash, 2009) that securing the impact of student researcher initiatives on the existing school policies and practices has been the most difficult challenge to overcome. Though we concluded that the student research experience contributed to the individual development of participating high school students, we could observe through informal conversations that the impact of their experience on their school's improvement was limited to an increased awareness from the involved teachers to listen and attend to student perspectives. In Portugal, high schools are still not much inclined to recognize these kinds of extracurricular activities valuing, instead, activities of academic preparation to national exams that have a huge weight both in competitive access to higher education and in school rankings disseminated in the media. Therefore, it is difficult for schools to put the effort in developing those conditions that Mitra (2009) pointed as being key in the development of successful youth-adult partnerships, namely, providing time for collaboration and to foster more balanced relationships that challenge the existing student and adult roles.

Despite these constraints, there is much potential to be explored in terms of students' skills gains, specifically in researching and analysing social issues. In times in which Social Sciences in general and Education Sciences specifically seem to lose some terrain in the sphere of Research and Development, we defend the seemingly unexplored potential of student researchers' projects also to high school students' awareness and valuing of informed Education Sciences research in school and curriculum improvement. This awareness is not only important for their current participation in school improvement initiatives, but also for their future views of the importance of valuing Education Sciences in other fields of knowledge and work.

\section{Acknowledgments}

The authors would like to express their gratitude to the Educational Department of the Municipality of Porto (Câmara Municipal do Porto) who promoted and funded the partnership that made this study possible and to the participant teachers and students who enthusiastically engaged in the partnership.

\section{Funding}

The author(s) disclosed receipt of the following financial support for the research, authorship, and/or publication of this article: This work was supported by the Portuguese Foundation for Science and Technology (FCT) and by the European Social Fund - Human Capital Operational Programme (POCH) from Portugal 2020 Programme -, in the framework of the contract established under the transitional rule of Decree Law 57/2016, amended by Law 57/2017. It was supported also by the Portuguese Government, through the FCT, under CIIE's multi-annual funding [grants no. UID/CED/00167/2019, UIDB/00167/2020 and UIDP/00167/2020].

\section{Note}

1. Information on the school retrieved from the Portuguese Ministry of Education Statistics portal about schools 'InfoEscolas' online in http://infoescolas.mec.pt/ (18-02-2021).

\section{References}

Bland, D., \& Atweh, B. (2007). Students as researchers: Engaging students' voices in PAR. Educational Action Research, 15(3), 337-349. https://doi.org/10.1080/09650790701514259 
Bourke, R., \& Loveridge, J. (2018). Using student voice to challenge understandings of educational research, policy and practice. In R. Bourke, \& J. Loveridge (Eds.), Radical collegiality through student voice: Educational experience, policy and practice (pp. 1-16). Springer.

Carrington, S., Bland, D. C., \& Brady, K. (2010). Training young people as researchers to investigate engagement and disengagement in the middle years. International Journal of Inclusive Education, 14(5), 449462. https://doi.org/10.1080/13603110802504945

César, M., \& Oliveira, I. (2005). The curriculum as a tool for inclusive participation: Students' voices in a case study in a Portuguese multicultural school. European Journal of Psychology of Education, 20(1), 29-43. https://doi.org/10.1007/bf03173209

Cook-Sather, A. (2012). Translating learners, researchers, and qualitative approaches through investigations of students' experiences in school. Qualitative Research, 13(3), 352-367. https://doi. org $/ 10.1177 / 1468794112451022$

Cook-Sather, A. (2018). Tracing the evolution of student voice in educational research. In R. Bourke, \& J. Loveridge (Eds.), Radical collegiality through student voice: Educational experience, policy and practice (pp. 17-38). Springer.

Davies, P. M. (2011). Student participation in school ICT policy-making: A case of students as researchers. Management in Education, 25(2), 71-77. https://doi.org/10.1177/0892020611399609

Fielding, M. (2001). Students as radical agents of change. Journal of Educational Change, 2(2), 123-141. https://doi.org/10.1023/a:1017949213447

Fielding, M. (2004a). 'New wave' student voice and the renewal of civic society. London Review of Education, 2(3), 197-217. https://doi.org/10.1080/1474846042000302834

Fielding, M. (2004b). Transformative approaches to student voice: Theoretical underpinnings, recalcitrant realities. British Educational Research Journal, 30(2), 295-311. https://doi.org/10.1080/0141192 042000195236

Fielding, M. (2011). Patterns of partnership: Student voice, intergenerational learning and democratic fellowship. In N. Mockler, \& J. Sachs (Eds.), Rethinking educational practice through reflexive inquiry: Essays in honour of Susan Groundwater-Smith (pp. 61-75). Springer.

Fielding, M., \& Bragg, S. (2003). Students as researchers: Making a difference. Consulting Pupils about Teaching and Learning. Pearson Publishing.

Fine, M., Torre, M. E., Burns, A., \& Payne, Y. A. (2007). Youth research/participatory methods for reform. In D. Thiessen, \& A. Cook-Sather (Eds.), International handbook of student experience in elementary and secondary school (pp. 805-828). Springer.

Gonzalez, T. E., Hernandez-Saca, D. I., \& Artiles, A. J. (2017). In search of voice: Theory and methods in K-12 student voice research in the US, 1990-2010, Educational Review, 69(4), 451-473.

Goodson, I. F. (2005). Learning curriculum, and life politics. Routledge.

Kellett, M. (2005). How to develop children as researchers: A step by step guide to teaching the research process. SAGE Publications Ltd.

Kuhn, D., Iordanou, K., Pease, M., \& Wirkala, C. (2008). Beyond control of variables: What needs to develop to achieve skilled scientific thinking? Cognitive Development, 23(4), 435-451. https://doi.org/10.1016/j. cogdev.2008.09.006

Leat, D., \& Reid, A. (2012). Exploring the role of student researchers in the process of curriculum development. The Curriculum Journal, 23(2), 189-205. https://doi.org/10.1080/09585176.2012.678691

Lundy, L., \& Cook-Sather, A. (2016). Children's rights and student voice: Their intersection and the implications for curriculum and pedagogy. In D. Wyse, L. Hayward, \& J. Pandya (Eds.), The SAGE handbook of curriculum, pedagogy and assessment (Vol. 1, pp. 263-277). SAGE.

Menezes, I., \& Ferreira, P. (2014). Cidadania participatória no cotidiano escolar: A vez e a voz das crianças e dos jovens. Educar em Revista, 53, 131-147. https://doi.org/10.1590/0104-4060.36586

Messiou, K. (2014). Working with students as co-researchers in schools: A matter of inclusion. International Journal of Inclusive Education, 18(6), 601-613. https://doi.org/10.1080/13603116.2013.802028

Messiou, K., Ainscow, M., Echeita, G., Goldrick, S., Hope, M., Paes, I., Sandoval, M., Simon, C., \& Vitorino, T. (2016). Learning from differences: A strategy for teacher development in respect to student diversity. School Effectiveness and School Improvement, 27(1), 45-61. https://doi.org/10.1080/09243453.2014.9 66726 
Ministério da Educação. (2016). A voz dos alunos do secundário. Paper presented at the Conferência Currículo para o Século XXI - A Voz dos Alunos, Auditório da Escola Superior de Educação e Ciências Sociais do Instituto Politécnico de Leiria. http://www.dge.mec.pt/sites/default/files/Curriculo/Conferencia_Voz_ Alunos/a_voz_dos_alunos_secundario.pdf

Mitra, D. L. (2009). Strengthening student voice initiatives in high schools: An examination of the supports needed for school-based youth-adult partnerships. Youth \& Society, 40(3), 311-335. https://doi. org $/ 10.1177 / 0044118 \times 08316211$

Mockler, N., \& Groundwater-Smith, S. (2015). Approaches to student voice: 'Empowerment', 'evidencebased practice' and participation. In N. Mockler, \& S. Groundwater-Smith (Eds.), Engaging with student voice in research, education and community: Beyond legitimation and guardianship (pp. 37-50). Springer International Publishing.

Morgan, B., \& Porter, A. (2011). Student researchers exploring teaching and learning: Processes and issues. In G. Czerniawski, \& W. Kidd (Eds.), The student voice handbook: Bridging the academic/practitioner divide (pp. 119-131). Emerald.

Mouraz, A, \& Sousa, A. (2016). An institutional approach to first-year adjustment: The 'Projeto FEUP' case study of a Portuguese University. Journal of Hispanic Higher Education, 15(3), 221-239. https://doi. org/10.1177/1538192715592928

Pereira, F., Mouraz, A., \& Figueiredo, C. (2014). Student Participation in School Life: The "Student Voice" and Mitigated Democracy. Croatian Journal of Education: Hrvatski časopis za odgoj i obrazovanje, 16(4), 935-975. https://doi.org/10.15516/cje.v16i4.742

Quintero, D. L. (2010). Students as researchers in an inquiry based classroom. Paper presented at the AGU Fall meeting abstracts. https://ui.adsabs.harvard.edu/\#abs/2010AGUFMED53A0509Q

Roberts, A., \& Nash, J. (2009). Enabling students to participate in school improvement through a Students as Researchers programme. Improving Schools, 12(2), 174-187.https://doi.org/10.1177/1365480209106590

Smit, B. H. J. (2013). Young people as co-researchers: Enabling student participation in educational practice. Professional Development in Education, 39(4), 550-573. https://doi.org/10.1080/19415257.2013.796297

Thomson, P., \& Gunter, H. (2006). From 'consulting pupils' to 'pupils as researchers': A situated case narrative. British Educational Research Journal, 32(6), 839-856. https://doi.org/10.1080/01411920600989487

Torres, A. C., \& Mouraz, A. (2015). Students' transition experience in the 10th year of schooling: Perceptions that contribute to improving the quality of schools. Improving Schools, 18(2), 127-141. https://doi. org/10.1177/1365480215581460

United Nations. (1989). United Nations convention on the rights of the child. United Nations. 